\title{
PENGARUH PROMOSI DAN WORD OF MOUTH TERHADAP KEPUTUSAN PEMBELIAN PRODUK XYZ DONUT
}

\author{
Budi Prasetiyo \\ Fakultas Ekonomi Universitas Nasional Pasim \\ nararitelclub@gmail.com \\ Taopik Hidayat \\ Fakultas Ekonomi Universitas Nasional Pasim \\ Taopik1989@gmail.com
}

\begin{abstract}
ABSTRAK
Dunia bisnis terus mengikuti kemajuan teknologi modern dalam berbagai hal termasuk strategi pemasaran. Hal ini memunculkan suatu peningkatan dalam penyebaran informasi yang lebih cepat sampai kepada calon konsumen sehingga saat produk muncul di media maka tingkat perbincangan (word of mouth) mengenai produk lebih cepat dan lebih banyak dari setiap orang yang melihat atau membelinya. Penelitian ini bertujuan untuk mengetahui pengaruh promosi dan word of mouth terhadap keputusan pembelian produk XYZ Donut di Bandung baik secara parsial maupun simultan. Penelitian ini menggunakan pendekatan kuantitatif dengan sampel yang terdiri dari 100 orang konsumen XYZ Donut. Instrumen penelitian ini menggunakan kuesioner dan dianalisis dengan menggunakan metode analisis jalur. Hasil penelitian ini menunjukan bahwa promosi dan word of mouth secara parsial dan simultan berpengaruh terhadap keputusan pembelian dengan nilai koefisien determinasi sebesar 83,7\%, dan sisanya sebesar 16,3\% dipengaruhi oleh faktor lain yang tidak diteliti.
\end{abstract}

Kata Kunci : Promosi, Word of Mouth, Keputusan Pembelian.

\section{PENDAHULUAN}

Di era globalisasi sekarang ini, perkembangan dunia usaha semakin pesat. Hal itu dapat dilihat dari perkembangan pengetahuan, kemajuan teknologi dan perkembangan arus informasi yang harus disampaikan oleh perusahaan untuk memenuhi kebutuhan informasi pengguna. Perkembangan ini diiringi dengan persaingan usaha yang begitu ketat dan kompetitif. Persaingan usaha yang ada perlu diimbangi dengan suatu pemikiran yang kritis dan pemanfaatan sumber daya perusahaan secara optimal. Dengan demikian perusahaan dapat bersaing dengan perusahaan lain baik perusahaan dalam negeri maupun luar negeri. Persaingan perusahaan yang begitu kompetitif, harus didukung dengan promosi yang tepat dan baik. Pemilihan media promosi akan berpengaruh pada minat dan ketertarikan konsumen terhadap produk perusahaan. Berbagai bentuk promosi yang dilakukan 
perusahaan harus menunjukan ciri khas atau keunggulan dari setiap produk.

Seiring dengan perkembangan teknologi yang semakin canggih, saat ini penggunaan internet menjadi salah satu pilihan media promosi bagi perusahaan untuk memasarkan suatu produk atau jasa yang disebut dengan istilah e-marketing. $E$-marketing adalah sisi pemasaran dari $e$ commerce, yang merupakan kegiatan perusahaan untuk mengkomunikasikan sesuatu, mempromosikan, dan menjual barang atau jasa melalui internet (Kotler dan Armstrong, 2012:278). Pemasaran dengan strategi promosi melalui internet khususnya dengan social media dapat meningkatkan penjualan secara luas dan tidak memerlukan biaya pemasaran yang mahal. Konsumen juga akan lebih mudah untuk mencari informasi mengenai produk yang ingin mereka beli karena tidak perlu tatap muka secara langsung.

Melihat banyaknya pengakses media sosial di Indonesia dengan segala kemudahan perangkat yang dimiliki saat ini, menjadi suatu peluang bisnis yang sangat baik bagi setiap bidang. Semua orang memanfaatkan media sosial untuk mencari segala macam informasi tentang berbagai macam produk. Promosi merupakan salah satu hal terpenting dalam proses pemasaran, dimana promosi akan menyampaikan informasi mengenai perusahaan dan produk yang dipasarkan kepada konsumen. Hasil yang didapatkan dari promosi ini tergantug dari strategi yang dilakukan oleh perusahaan mengenai media, kreatifitas dan konsistensi dalam menciptakannya.

Tidak dapat dipungkiri penggunaan media sosial untuk memasarkan produk secara otomatis akan membentuk strategi komunikasi pemasaran yang efektif yaitu word of mouth. "Word of mouth merupakan kegiatan pemasaran melalui perantara orang ke orang, baik secara lisan, tulisan, maupun alat komunikasi elektronik yang berhubungan dengan pengalaman pembelian atau pengalaman menggunakan produk" (Kotler dan Keller, 2009:512).

Jenis promosi ini lebih memiliki keunggulan kompetitif dalam menyampaikan informasi suatu bisnis. Hal ini dikarenakan word of mouth muncul secara natural dari pendapat lingkungan sosial yang di rasa lebih jujur dan tidak ada motif-motif dalam menyampaikan suatu informasi kepada konsumen lainya. Ketika teknologi semakin canggih maka tidak akan ada lagi yang membatasi word of mouth pada situasi percakapan tatap muka, namun bisa melalui telepon maupun media 
sosial. Ditambah lagi dengan kondisi masyarakat sekarang ini lebih cenderung memanfaatkan perangkat smartphone untuk mengakses internet.

Salah satu perusahaan yang memanfaatkan strategi promosi ini adalah XYZ Donut. Dengan membuat akun di media sosial instagram XYZ Donut membangun pasar melalui hubungan jual beli secara online dan offline. Selain media promosi yang digunakan mengikuti perkembangan zaman, produk yang dimiliki XYZ Donut pun mampu menarik perhatian masyarakat karena keunikan dan inovasinya dalam menciptakan produk makanan donat yang memiliki cita rasa yang baik serta bentuk unik dan dapat dikreasikan sesuai keinginan konsumen. Dalam waktu yang terbilang cukup singkat XYZ Donut berhasil mengembangkan bisnisnya hingga membuka cabang di tempat lain.

Hal ini menunjukan XYZ Donut telah mendapat respon positif dari para pengguna media sosial yang mengapresiasi produk mereka lewat promosi online dan ikut menyebarluaskan secara langsung maupun tidak langsung kepada pengguna lain tentang produk ini atau yang disebut dengan istilah berita dari mulut ke mulut. Fenomena ini sedang terjadi dalam berbagai bidang yang berhubungan dengan media sosial baik secara positif ataupun negatif. Pada kesempatan ini penulis tertarik untuk meneliti hal ini yang terjadi pada XYZ Donut sebagai pengusaha di bidang kuliner di kota Bandung.

Berdasarkan survey awal ternyata apresiasi masyarakat dari hasil promosi di media sosial sangat positif dan tumbuh pesat. Namun dari hasil penelitian awal yang penulis lakukan terhadap konsumen ada beberapa hal yang dinilai sebagai kekurangan dari perusahaan bagi konsumen.

Berdasarkan survey pendahuluan yang telah dilakukan dapat diperoleh informasi bahwa beberapa hal yang berupa media promosi seperti pemajangan iklan masih kurang jelas informasinya dan kurang banyak iklannya terutama di cabang toko pusat perbelanjaan, konsumen merasa kurang jelas petunjuk lokasi toko berada dan kurang dipahaminya promosi yang sedang berlangsung. Dari kualitas promosi sendiri konsumen merasa XYZ Donut masih kurang memberikan promosi yang menarik seperti potongan harga dan bonus produk Satu hal lagi yang dinilai kurang oleh konsumen adalah kenyamanan tempat terutama pada cabang toko yang berada di pusat 
perbelanjaan. Setiap perusahaan akan selalu berharap feedback yang baik dari konsumen, maka untuk memaksimalkanya pihak perusahaan harus memberikan pelayanan terbaiknya dengan meningkatkan segala aspek yang menunjang proses jual beli produknya.

Strategi pemasaran yang dilakukan XYZ Donut dengan menggunakan media sosial ini juga dilakukan oleh para pelaku usaha lain sejenis sehingga semakin banyak para pesaing usahanya. Dengan demikian semakin banyak pula pertimbangan konsumen dalam menentukan keputusan pembelian seperti kemudahan mendapatkan informasi, kenyamanan hingga kualitas produknya.

Berdasarkan uraian diatas dengan melihat fenomena yang terjadi mengenai promosi di media sosial dan word of mouth yang sangat berkembang maka penulis tertarik untuk menyusun usulan penelitian dengan judul "Pengaruh Promosi dan Word of Mouth terhadap Keputusan Pembelian Produk XYZ Donut"

Adapun tujuan penelitian ini adalah sebagai berikut:

1. Untuk mengetahui pengaruh promosi terhadap keputusan pembelian produk XYZ Donut
2. Untuk mengetahui pengaruh word of mouth terhadap keputusan pembelian produk XYZ Donut

3. Untuk mengetahui pengaruh promosi dan word of mouth terhadap keputusan pembelian produk XYZ Donut

Hipotesis penelitian yang akan dibuktikan adalah:

1. H1: Promosi berpengaruh terhadap keputusan pembelian XYZ donut

2. H2: Word Of Mouth berpengaruh terhadap keputusan pembelian $\mathrm{XYZ}$ donut

3. H3: Promosi dan Word Of Mouth berpengaruh terhadap keputusan pembelian XYZ donut.

\section{KAJIAN PUSTAKA}

\subsection{Pengertian Promosi}

Dalam mengelola suatu sistem komunikasi pemasaran memerlukan suatu rancangan strategi dan programprogram penjualan yang efektif dan efisien. Promosi penjualan merupakan unsur kunci dalam kampanye perusahaan dan promosi yang paling baik adalah promosi yang memberikan kepuasan terhadap pelanggan. Dengan demikian promosi perlu ditangani secara cermat karena merupakan hal yang menyangkut cara bagaimana berkomunikasi dengan pelanggan dan menyangkut seberapa 
besar biaya yang dikeluarkan untuk biaya ini yang tentunya harus disesuaikan dengan kondisi dan kemampuan perusahaan.

Menurut Fandy Tjiptono dkk (2008:219) Promosi dapat didefinisikan sebagai suatu bentuk komunikasi pemasaran, komunikasi pemasaran adalah suatu aktivitas pemasaran yang berusaha menyebarkan informasi, mempengaruhi atau membujuk dan/atau mengingatkan pasar sasaran atas perusahaan dan produknya agar bersedia menerima, membeli dan loyal pada produk yang ditawarkan perusahaan yang bersangkutan.

Sedangkan menurut Basu Swastha dan Irawan (2008:349) promosi adalah arus informasi atau persuasi satu arah yang dibuat untuk mengarahkan seseorang atau organisasi kepada tindakan yang menciptakan pertukaran dalam pemasaran. Kegiatan promosi bukan saja berfungsi sebagai alat komunikasi antara perusahaan dengan konsumen, melainkan juga sebagai alat untuk mempengaruhi konsumen dalam kegiatan pembelian produk sesuai dengan keinginannya. Pendapat lain dikemukakan oleh Kotler dan Armstrong (2012:76) yang menyatakan bahwa promosi adalah aktivitas yang menyampaikan manfaat produk dan membujuk pelanggan untuk membelinya. Dengan adanya promosi menyebabkan orang yang sebelumnya tidak tertarik untuk membeli suatu produk akan menjadi tertarik dan mencoba produk sehingga konsumen melakukan pembelian Dengan demikian maka promosi merupakan kegiatan perusahaan yang dilakukan dalam rangka memperkenalkan produk kepada konsumen sehingga dengan kegiatan tersebut konsumen tertarik untuk melakukan pembelian.

\subsection{Pengertian Word of Mouth}

Salah satu bentuk promosi yang alami dan berbiaya paling murah adalah informasi melalui perantara orang ke orang melalui lisan, tulisan ataupun alat komunikasi elektronik atau dikenal dengan istilah word of mouth. Kondisi ini lebih banyak terjadi antara konsumen ke konsumen, dimana mereka yang telah merasakan atau mendapatkan produk jasa atau barang dari suatu merek akan membagikan pengalaman mereka baik atau buruk kepada orang lain sebagai rasa kepuasan atau sebaliknya. Hal ini akan memberikan pengaruh positif ataupun negatif terhadap penerima pesan, maka produsen akan menerima efek dari 
promosi ini secara langsung ataupun tidak langsung.

Beberapa ahli telah mengemukakan pendapatnya tentang pengertian dari word of mouth ini sesuai dengan perkembangan zaman. Komunikasi dari mulut ke mulut menjadi lebih efektif karena informasi dari teman akan lebih dipercaya dibandingkan informasi dari brosur. Salah satu sumber pengetahuan konsumen terhadap merek produk disebabkan adanya komunikasi dari mulut ke mulut sebab sebuah percakapan yang didesain secara online maupun offline memiliki multiple effect, non hierarchy horizontal dan mutasional (Ali Hasan 2010:29).

Menurut Sumardy (2011:630) Word of mouth adalah tindakan penyediaan informasi oleh kosumen kepada konsumen yang lain. Word of mouth tidak membutuhkan biaya yang begitu besar namun dapat memperoleh efektifitas yang sangat besar. Didukung lagi kebiasaan masyarakat Indonesia yang senang berkumpul dan bersosialisasi untuk bercerita akan hal-hal yang mereka sukai dan alami. Kotler dan Keller (2009:512) menyatakan word of mouth merupakan kegiatan pemasaran melalui perantara orang ke orang, baik secara lisan, tulisan, maupun alat komunikasi elektronik yang berhubungan dngan pengalaman pembelian atau pengalaman menggunakan produk. Informasi yang tercipta dari mulut ke mulut bukanlah hal yang subyektif yang dapat dinilai oleh produsen saja tetapi hal itu harus dibuktikan kebenarannya oleh pihak lain termasuk pembeli sehingga terkesan produk tersebut memang merupakan produk yang terbukti kualitasnya. Dengan demikian kualitas produk bukan hanya sebatas promosi semata melainkan benar-benar sebuah informasi yang meyakinkan.

Word of mouth merupakan bagian dari strategi promosi dalam kegiatan pemasaran yang menggunakan orang ke orang yang puas untuk meningkatkan kesadaran produk dan menghasilkan tingkat penjualan tertentu. Komunikasi dari mulut ke mulut menyebar dari jaringan bisnis, sosial dan masyarakat yang dianggap sagat berpengaruh (Ali Hasan, 2010:230).

\subsection{Pengertian Keputusan Pembelian}

Keputusan pembelian merupakan Keputusan yang diambil konsumen untuk melakukan pembelian suatu produk melalui tahapan-tahapan yang dilalui konsumen sebelum melakukan pembelian yang meliputikebutuhan yang 
dirasakan, kegiatan sebelum membeli, perilaku waktu memakai dan perasaan setelah membeli (Kotler dan Keller, 2009:166). Keputusan pembelian konsumen adalah keputusan pembelian konsumen akhir dan rumah tangga yang membeli barang dan jasa untuk konsumsi pribadi.

Sedangkan menurut Fandy Tjiptono dkk (2008:19) mengemukakan bahwa keputusan pembelian konsumen adalah pemilihan satu tindakan dari dua atau lebih pilihan alternatif. Dari beberapa pengertian tersebut dapat disimpulkan bahwa keputusan pembelian konsumen adalah pemilihan salah satu dari beberapa alternatif penyelesaian masalah yang dikumpulkan oleh konsumen dan mewujudkan dengan tindak lanjut yang nyata. Setelah proses tersebut barulah konsumen dapat mengevaluasi pilihannya dan menentukan sikap yang akan diambil selanjutnya.

\subsection{Teori Hubungan antar variabel} Promosi (X1), Word of Mouth (X2) dan Keputusan Pembelian (Y)

a. Promosi (X1) dan Word of Mouth (X2)

Promosi adalah aktivitas yang menyampaikan manfaat produk dan membujuk pelanggan untuk membelinya (Kotler \& Armstrong, 2012:76). Media sosial sebagai salah satu sarana untuk melakukan kegiatan promosi menjadi hal yang sangat diminati oleh para pengusaha pada masa ini untuk membantu kegiatan pemasaran produk atau jasanya. Berbagai media promosi yang tersedia untuk promosi akan membentuk suatu media promosi lain yang umum dan alami yang dilakukan oleh konsumen yang telah mengetahui produk kita baik secara langsung ataupun tidak dengan cara menyampaikan secara pridadi kepada calon konsumen yang lain yang disebut dengan istilah word of mouth atau berita dari mulut ke mulut.

\section{b. Promosi terhadap Keputusan pembelian}

Promosi merupakan faktor penting dalam mewujudkan tujuan penjualan suatu perusahaan. Agar konsumen bersedia menjadi langganan, mereka terlebih dahulu harus dapat mencoba atau meneliti barang-barang yang diproduksi oleh perusahaan, akan tetapi mereka tidak akan melakukan hal tersebut jika kurang yakin terhadap barang itu. Disinilah perlunya mengadakan promosi yang terarah, karena diharapkan dapat memberikan pengaruh positif terhadap meningkatnya penjualan. 
Promosi merupakan salah satu variabel pemasaran yang dapat digunakan oleh konsumen sebagai acuan dalam memilih barang atau jasa yang diinginkan. Keterkaitan promosi dan keputusan pembelian adalah suatu cara memperkenalkan, mengkomunikasikan manfaat suatu barang atau jasa dan mengajak konsumen untuk menggunakan produk yang ditawarkan. Apabila konsumen tertarik untuk menggunakan produk atau jasa yang ditawarkan maka akan menimbulkan perminttaan pasar. Sebaliknya jika konsumen tidak yakin dengan promosi yang dilakukan maka tidak akan menciptakan permintaan sehingga dikatakan promosi mempengaruhi keputusan pembelian konsumen (Fandy Tjiptono dkk, 2008:24).

\section{c. Word of mouth terhadap Keputusan pembelian}

Komunikasi word of mouth sangat efektif dalam mengenalkan sebuah produk atau layanan jasa, namun pada kenyataannya hal ini sulit untuk dikontrol terkait pendapat negatif berupa rumor yang tidak benar yang dapat dengan cepat menyebar luas. Word of mouth dapat dengan cepat diterima oleh pelanggan karena yang menyampaikan adalah seseorang yang terpercaya seperti pakar, teman, keluarga serta publikasi media massa. Word of mouth juga cepat diterima sebagai referensi karena pelanggan jasa biasanya sulit mengevaluasi jasa yang belum dibelinya atau belum dirasakannya sendiri.

Sebagian besar keputusan pembelian dipengaruhi oleh rekomendasi dari teman atau keluarga, yang berarti disini rekomendasi mempunyai kekuatan pengaruh yang sangat besar pada keputusan pembelian seseorang terhadap suatu produk. Tidak peduli perusahaan kecil atau besar, word of mouth tetap menjadi praktik pemasaran yang paling mendominasi pengaruh terhadap keputusan pembelian konsumen terhadap produk apapun (Sumardy, 2011:66).

\section{d. Promosi dan Word of Mouth terhadap keputusan pembelian}

Ketiga variabel di atas pernah dibahas pada penelitian sebelumnya, diantaranya dalam penelitian Bagas Aji Pamungkas (2016) yang dilakukan terhadap konsumen kedai Bontacos Jombang hasilnya menyatakan bahwa promosi menggunakan media sosial dan word of mouth secara parsial dan simultan memiliki pengaruh terhadap keputusan pembelian. Begitu juga dengan hasil penelitian Antoni Prasetyo (2016) yang dilakukan terhadap konsumen kedai 
Kopiganes Surabaya mengatakan bahwa promosi di media sosial dan word of mouth secara bersama-sama mempunyai pengaru yang signifikan terhadap keputusan pembelian konsumen terutama faktor word of mouth yang menjadi paling dominan.

\subsection{Paradigma Penelitian}

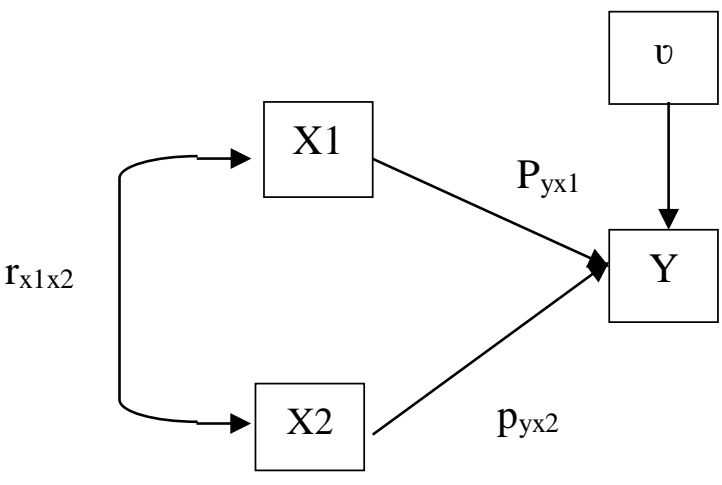

\section{METODE PENELITIAN}

Penelitian ini dilaksanakan XYZ Donut yang memiliki kantor pusat di Kota Bandung dan memiliki tiga toko cabang.

Dalam penelitian ini peneliti akan meneliti berapa besar pengaruh promosi dan word of mouth terhadap keputusan pembelian produk XYZ Donut dengan menggunakan metode analisis jalur. Adapun dalam pengujian hipotesis penelitian akan menggunakan uji $\mathrm{F}$ dan uji t sebagai alat bantunya. Unit analisis dalam penelitian ini adalah individu, konsumen XYZ Donut.
Sampel yang akan diambil sebagai responden yaitu sebanyak 100 orang. Peneliti melakukan teknik penarikan sampel Stratified Random Sampling karena terdiri dari beberapa toko cabang dengan perhitungan alokasi proporsional dari setiap toko yaitu:

Toko Cabang A: $\quad \frac{3574}{6741} \times 100=53$

Toko Cabang B: $\quad \frac{1382}{6741} \times 100=20$

Toko Cabang C: $\quad \frac{1785}{6741} \times 100=27$

Jadi total jumlah sampel dari ketiga cabang adalah $53+20+27=100$ orang. Dalam penelitian ini instrumen yang akan dipakai dalam pengumpulan data adalah kuesioner dengan menggunakan skala likert. Skala Likert digunakan untuk melihat seberapa besar tingkat persetujuan responden terhadap pernyataan yang diajukan mulai dari yang sangat tidak setuju hingga yang sangat setuju.

Dalam penelitian yang menggunakan kuesioner harus dilakukan uji validitas, untuk menguji validitas tersebut penulis akan menggunakan nilai korelasi pearson. Menurut Bambang S.Soedibjo (2013) kriteria valid bila nilai koefisien korelasi bernilai lebih dari 0,3

Selain harus melalui uji validitas, uji reliabilitas harus juga dilakukan. Uji ini dilakukan untuk melihat stabilitas dan 
konsistensi hasil pengukuran. Uji reliabilitas dilakukan dengan metode internal consistency, dengan menggunakan rumus alpha Cronchach's.

Menurut sekaran dalam Bambang S. Soedibjo (2013), bila nilainya berada dalam kisaran 0,6 -0,8 maka instrumen tersebut dikatakan baik dan apabila nilainya lebih lebih 0,8 maka dikatakan sangat baik.

Variabel yang diteliti dalam penelitian adalah: Variabel Eksogen: Promosi (X1) dan Word Of Mouth (X2). Variabel Endogen: Keputusan Pembelian (Y)

Adapun Operasional variabel adalah sebagai berikut:

Tabel 1.Tabel Operasional Variabel

\begin{tabular}{|c|c|c|}
\hline Variabel & Dimensi & Indikator \\
\hline \multirow{9}{*}{ Promosi } & \multirow{3}{*}{ Periklanan } & Tujuan iklan \\
\hline & & Pesan iklan \\
\hline & & Media yang digunakan \\
\hline & \multirow{3}{*}{$\begin{array}{l}\text { Promosi } \\
\text { penjualan }\end{array}$} & Frekuensi penjualan \\
\hline & & Kualitas promosi \\
\hline & & Ketepatan waktu \\
\hline & \multirow{3}{*}{$\begin{array}{l}\text { Hubungan } \\
\text { masyarakat }\end{array}$} & Berita \\
\hline & & Kegiatan pelayanan \\
\hline & & Identitas perusahaan \\
\hline \multirow{4}{*}{$\begin{array}{c}\text { Word of } \\
\text { Mouth }\end{array}$} & \multirow{2}{*}{$\begin{array}{c}\text { Buz\& } \\
\text { Viral }\end{array}$} & Sumber \\
\hline & & Topik/Bahasan \\
\hline & \multirow{2}{*}{$\begin{array}{l}\text { Opinion } \\
\text { Leader }\end{array}$} & Kepercayaan Individu \\
\hline & & Kelompok Konsumen \\
\hline
\end{tabular}

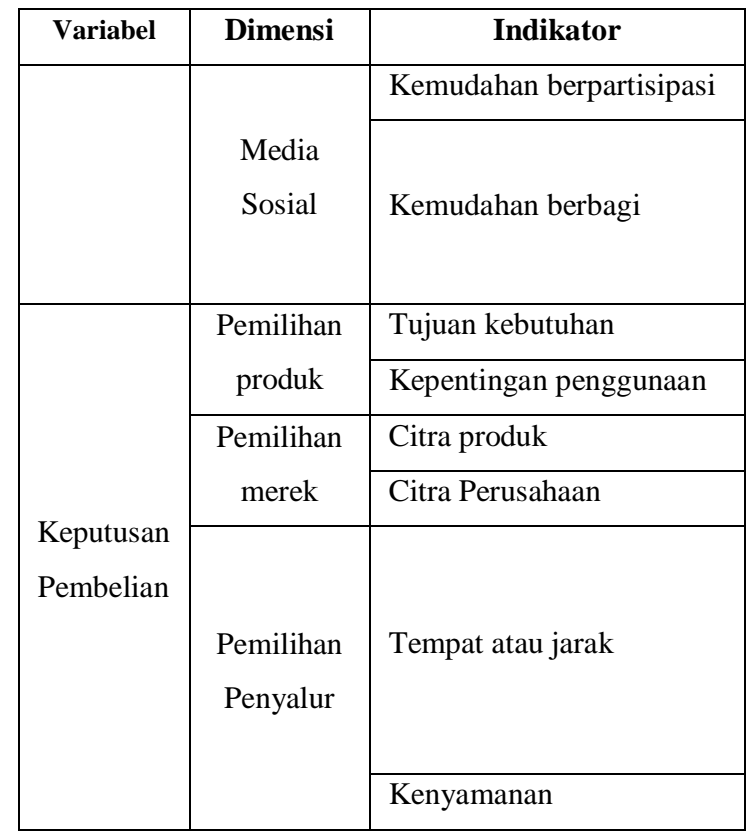

\section{HASIL DAN PEMBAHASAN}

Penelitian memerlukan data yang betul valid dan reliabel. Dalam rangka urgensi ini, maka kuesioner sebelum digunakan sebagai data penelitian primer, terlebih dahulu diujicobakan ke sampel uji coba penelitian. Uji coba ini dilakukan untuk memperoleh bukti sejauh mana ketepatan dan kecermatan alat ukur dalam melakukan fungsi ukurnya

Uji validitas yang telah dilakukan menandakan bahwa instrumen valid karena nilai koefisien korelasi semuanya memiliki angka > 0,3. Hasil pengujiannya dapat dilihat dalam tabel berikut: 
Tabel 2. Hasil Uji Validitas Indikator Promosi

\begin{tabular}{|c|c|c|}
\hline $\begin{array}{c}\text { Indikator } \\
\text { Pernyataan }\end{array}$ & $\begin{array}{c}\text { Hasil R } \\
\text { Hitung }\end{array}$ & Ket \\
\hline X1.1 & 0,331 & Valid \\
\hline X1.2 & 0,783 & Valid \\
\hline X1.3 & 0,737 & Valid \\
\hline X1.4 & 0,697 & Valid \\
\hline X1.5 & 0,836 & Valid \\
\hline X1.6 & 0,704 & Valid \\
\hline X1.7 & 0,568 & Valid \\
\hline X1.8 & 0.700 & Valid \\
\hline X1.9 & 0,509 & Valid \\
\hline
\end{tabular}

Tabel 3. Hasil Uji Validitas Indikator Word Of Mouth

\begin{tabular}{|c|c|c|}
\hline $\begin{array}{c}\text { Indikator } \\
\text { Pernyataan }\end{array}$ & $\begin{array}{c}\text { Hasil R } \\
\text { Hitung }\end{array}$ & Ket \\
\hline $\mathrm{X} 2.1$ & 0,639 & Valid \\
\hline $\mathrm{X} 2.2$ & 0,602 & Valid \\
\hline $\mathrm{X} 2.3$ & 0,644 & Valid \\
\hline $\mathrm{X} 2.4$ & 0,813 & Valid \\
\hline $\mathrm{X} 2.5$ & 0,663 & Valid \\
\hline $\mathrm{X} 2.6$ & 0,599 & Valid \\
\hline
\end{tabular}

Tabel 4. Hasil Uji Validitas Indikator Keputusan Pembelian

\begin{tabular}{|c|c|c|}
\hline $\begin{array}{c}\text { Indikator } \\
\text { Pernyataan }\end{array}$ & $\begin{array}{c}\text { Hasil R } \\
\text { Hitung }\end{array}$ & Ket \\
\hline Y.1 & 0,608 & Valid \\
\hline Y.2 & 0,57 & Valid \\
\hline Y.3 & 0,744 & Valid \\
\hline Y.4 & 0,835 & Valid \\
\hline Y.5 & 0,796 & Valid \\
\hline Y.6 & 0,835 & Valid \\
\hline
\end{tabular}

Untuk uji realiabilitas, secara keseluruhan pertanyaan pembentuk variabel promosi, variabel word of mouth, dan variabel keputusan pembelian realibel, karena angka Cronbach Alpha > 0,6. Hasil pengujian dapat dilihat dalam tabel berikut:

Tabel 5. Hasil Uji Reliabilitas

\begin{tabular}{|c|c|c|}
\hline Variabel & $\begin{array}{c}\text { Cronbach } \\
\text { Alpha }\end{array}$ & Ket \\
\hline X1 & 0,827 & Baik \\
\hline X2 & 0,740 & Baik \\
\hline Y & 0,821 & Baik \\
\hline
\end{tabular}

Metode Analisis jalur dilakukan dengan menggunakan SPSS. Hasil outputnya disajikan dalam tabel berikut: 
Tabel 6. Hasil Output Coefficients

\begin{tabular}{|l|r|r|c|}
\hline & $\begin{array}{c}\text { Standardized } \\
\text { Coefficients Beta }\end{array}$ & t hitung & Sign \\
\hline Konstanta &, 374 & $-2,980$ &, 004 \\
\hline Promosi &, 593 & 9,104 &, 000 \\
\hline $\begin{array}{l}\text { Word Of } \\
\text { Mouth }\end{array}$ & &, 000 \\
\hline
\end{tabular}

Catatan: Sumber telah diolah kembali

Tabel 7. Nilai Korelasi

\begin{tabular}{|c|c|c|c|}
\hline \multicolumn{4}{|c|}{ Correlations } \\
\hline & & Promosi & $\begin{array}{c}\text { Word Of } \\
\text { Mouth }\end{array}$ \\
\hline \multirow[t]{3}{*}{ Promosi } & $\begin{array}{l}\text { Pearson } \\
\text { Correlation }\end{array}$ & 1 &, $778^{* * *}$ \\
\hline & $\begin{array}{l}\text { Sig. (2- } \\
\text { tailed) }\end{array}$ & & ,000 \\
\hline & $\mathbf{N}$ & 100 & 100 \\
\hline \multirow{3}{*}{$\begin{array}{l}\text { Word Of } \\
\text { Mouth }\end{array}$} & $\begin{array}{l}\text { Pearson } \\
\text { Correlation }\end{array}$ &, $778^{* * *}$ & 1 \\
\hline & $\begin{array}{l}\text { Sig. (2- } \\
\text { tailed) }\end{array}$ & , 000 & \\
\hline & $\mathbf{N}$ & 100 & 100 \\
\hline
\end{tabular}

Tabel 8. Hasil Model Summary

\begin{tabular}{l|c|c|c|}
\hline Model & $\mathbf{R}$ & $\begin{array}{c}\text { R } \\
\text { Square }\end{array}$ & $\begin{array}{c}\text { Adusted } \\
\text { R Square }\end{array}$ \\
\hline 1 & $0,915^{\text {a }}$ & 0,837 & 0,834 \\
\hline
\end{tabular}

Tabel 9.Hasil ANOVA

\begin{tabular}{l|c|c|}
\hline Model & F & Sig. \\
\hline 1 & 249.410 & $0,000^{\mathrm{b}}$ \\
\hline
\end{tabular}

\subsection{Pengaruh promosi terhadap} keputusan pembelian produk XYZ Donut

Besarnya Pengaruh promosi terhadap keputusan pembelian XYZ Donut dapat diketahui melalui perhitungan sebagai berikut:

Pengaruh langsung

$=\operatorname{Pyx} 1 \times$ Pyx 1

$=0,374 \times 0,374$

$=0,1399$

Pengaruh tidak langsung

$=$ Pyx $1 \times \operatorname{rx} 1 \times 2 \times$ Pyx 2

$=0,374 \times 0,778 \times 0,593$

$=0,1725$

Total Pengaruh $=0,1399+0,1725$

$$
=0,3124
$$

Berdasarkan hasil perhitungan di atas dapat dilihat bahwa pengaruh variabel promosi terhadap keputusan pembelian produk XYZ Donut secara langsung sebesar 0,1399, sedangkan secara tidak langsung (korelatif melalui X2) sebesar 0,1725 dan pengaruh secara total dapat mempengaruhi perubahan dalam keputusan pembelian adalah sebesar 0,3124 atau sebesar 31,24\%.

Untuk menguji hipotesis "promosi berpengaruh terhadap keputusan pembelian XYZ Donut Bandung”. Berdasarkan angkat $t$ hitung dari tabel 6, diperoleh pengaruh variabel promosi 
terhadap keputusan pembelian berdasarkan uji t, dimana nilai t hitung sebesar 5,737 dengan sign.0,00. Artinya nilai signifikansinya $<0,05$ sehingga dapat disimpulkan bahwa variabel promosi memiliki pengaruh yang signifikan terhadap keputusan pembelian dan mendukung pernyataan yang dikemukakan oleh Fandy Tjiptono dkk (2008:24) dimana promosi mempengaruhi keputusan pembelian konsumen.

Berdasarkan hasil kesimpulan di atas, promosi mempunyai pengaruh terhadap keputusan pembelian sehingga XYZ donut dapat melakukan berbagai berbagai promosi seperti: memberikan potongan harga, bonus produk untuk jumlah pembelian tertentu dan pemberian gift.

\subsection{Pengaruh Word Of Mouth terhadap keputusan pembelian produk XYZ Donut}

Besarnya Pengaruh Word of Mouth terhadap keputusan pembelian XYZ Donut dapat diketahui melalui perhitungan sebagai berikut:

Pengaruh langsung

$=\operatorname{Pyx} 1 \times$ Pyx 1

$=0,593 \times 0,593$

$=0,3516$
Pengaruh tidak langsung

$=\operatorname{Pyx} 1 \times \mathrm{rx} 1 \mathrm{x} 2 \mathrm{x}$ Pyx 2

$=0,374 \times 0,778 \times 0,593$

$=0,1725$

Total Pengaruh $=0,3516+0,1725$

$$
=0,5241
$$

Berdasarkan hasil perhitungan di atas dapat dilihat bahwa pengaruh variabel Word of Mouth terhadap keputusan pembelian produk XYZ Donut secara langsung sebesar 0,3516, sedangkan secara tidak langsung (korelatif melalui X2) sebesar 0,1725 dan pengaruh secara total dapat mempengaruhi perubahan dalam keputusan pembelian adalah sebesar 0,5241 atau sebesar $52,41 \%$.

Untuk menguji hipotesis "Word Of Mouth berpengaruh terhadap keputusan pembelian XYZ Donut Bandung”. Berdasarkan angka t hitung dari tabel 6, diperoleh pengaruh variabel promosi terhadap keputusan pembelian berdasarkan uji t, dimana nilai t hitung sebesar 9,104 dengan signifikansinya 0,00 . Artinya nilai signifikansinya < 0,05 sehingga dapat disimpulkan bahwa variabel Word Of Mouth memiliki pengaruh yang signifikan terhadap keputusan pembelian sehingga mendukung teori yang dikemukakan oleh Sumardy (2011:66) dikatakan 
bahwa word of mouth mendominasi pengaruh terhadap keputusan pembelian konsumen

Berdasarkan hasil kesimpulan di atas, Word Of Mouth mempunyai pengaruh terhadap keputusan pembelian sehingga XYZ donut dapat melakukan berbagai berbagai aktivitas seperti: kemudahan mendapatkan informasi, kenyamanan toko hingga kualitas produknya.

\subsection{Pengaruh Promosi dan Word of} Mouth terhadap Keputusan

\section{Pembelian Produk XYZ Donut}

Untuk mengetahui seberapa besar persentase pengaruh promosi dan word of mouth terhadap keputusan pembelian dapat dilihat dari hasil olah data SPSS di tabel.

Dari tabel di atas terlihat pengaruh kedua variabel $\mathrm{X} 1$ dan $\mathrm{X} 2$ terhadap $\mathrm{Y}$ pada kolom nilai $\mathrm{R}$ Square yaitu 0,837 maka pengaruh yang lain diluar model adalah sisa dari nilai 1 dikurangi dengan nilai $R$ Square yaitu $1-0,837=0,163$.

Berdasarkan diagram di atas dapat dijelaskan bahwa korelasi antara promosi (X1) dan word of mouth (X2) sebesar 0,778, variabel promosi berpengaruh terhadap keputusan pembelian sebesar 0,374 , variabel word of mouth berpengaruh terhadap keputusan pembelian sebesar 0,593, dan variabel residu (gangguan) sebesar 0,163 . Maka dapat disimpulkan bahwa koefisien jalur word of mouth menjadi yang paling berpengaruh terhadap keputusan pembelian.

Uji $\mathrm{F}$ dilakukan untuk menguji hipotesis apakah ada pengaruh variabel eksogen promosi (X1) dan word of mouth (X2) terhadap variabel endogen keputusan pembelian (Y) secara simultan.

Berdasarkan nilai $\mathrm{F}$ hitung pada tabel 9, sebesar 3,09 dengan signifikansinya 0,00 (kurang dari 0,05), dapat diintrepretasikan bahwa terdapat pengaruh secara simultan antara variabel promosi dan word of mouth terhadap keputusan pembelian karena lebih besar. Hal ini didukung dengan hasil penelitian Antoni Prasetyo (2016) dan Bagas Aji Pamungkas (2016) bahwa ada pengaruh promosi dan word of mouth secara bersama-sama terhadap keputusan pembelian. 


\section{PENUTUP}

Berdasarkan hasil penelitian dan pembahasan: sebelumnya, maka dapat disimpulkan sebagai berikut:

1) Hipotesis pertama yang berbunyi Promosi berpengaruh terhadap keputusan pembelian XYZ donut terbukti kebenarannya. Adapun pengaruhnya sebesar $31,24 \%$.

2) Hipotesis kedua yang berbunyi Word Of Mouth berpengaruh terhadap keputusan pembelian XYZ donut terbukti kebenarannya. Adapun pengaruhnya sebesar $52,41 \%$.

3) Hipotesis ketiga yang berbunyi Promosi dan Word Of Mouth berpengaruh terhadap keputusan pembelian XYZ donut terbukti kebenarannya. Adapun pengaruh secara simultannya adalah sebesar $83,7 \%$.

\section{DAFTAR PUSTAKA}

Ali Hasan. 2010. Marketing dari Mulut ke Mulut. Yogyakarta: Media Pressindo.

Antoni Prasetyo. 2016. Pengaruh Strategi Promosi dan Word Of Mouth Terhadap Keputusan Pembelian pada Kopiganes.
Jurnal Ilmu dan Riset Manajemen Vol.5 No.1, Januari 2016.

Bagas Aji Pamungkas. 2016. Pengaruh Promosi di Media Sosial dan Word of Mouth Terhadap Keputusan Pembelian (Studi Kasus pada Kedai Bontacos, Jombang). Jurnal Komunikasi Vol.X No.02, September 2016:145-160.

Bambang S. Soedibjo. 2017. Pengantar Metode Penelitian. Bandung: Universitas Nasional Pasim.

Basu Swastha, Irawan. 2008. Manajemen Pemasaran Modern. Jakarta: Liberty.

Fandy Tjiptono, Gregorius Chandra, Dadi Adriana. 2008. Pemasaran Stratejik. Yogyakarta: Andi

Philip Kotler dan Gary Armstrong. 2012. Prinsip-prinsip Pemasaran. Jakarta: PT. INDEKS Kelompok Gramedia.

Philip Kotler dan Kevin Lane Keller. 2009. Manajemen Pemasaran 
Jilid 1 dan Jilid 14. Jakarta: Erlangga.

Sumardy. 2011. The Power of Word of Mouth Marketing. Jakarta:

Gramedia Pustaka Utama. 